\title{
Species Differentiation of Human Vaginal Lactobacilli
}

\author{
By M. ROGOSA \\ National Institute of Dental Research, National Institutes of Health, \\ Public Health Service, U.S. Department of Health, Education \\ and Welfare, Bethesda, Maryland, U.S.A. \\ AND M. ELISABETH SHARPE \\ National Institute for Research in Dairying, University of Reading
}

(Received 3 March 1960)

\section{SUMMARY}

The designation 'Döderlein's bacillus' for human vaginal strains of the genus Lactobacillis is vague and unsatisfactory. Thirty-five strains of lactobacilli from twenty-one normal non-pregnant women aged $21-40$ were isolated; c. $25 \%$ were heterofermentative. Of 21 isolates studied in detail, 14 were $L$. acidophilus and two were $L$. casei var. rhamnosus (Rogosa et al. 1953). The heterofermentative species comprised four strains of $L$. fermenti and one of $L$. cellobiosus (Rogosa et al. 1953). Glycogen fermentation, which was found only in certain strains of $L$. acidophilus, was a variable characteristic. In addition, Leuconostoc mesenteroides, which on examination of smears can be confused with short rod forms, was also isolated.

\section{INTRODUCTION}

At birth the human vagina is sterile and the vaginal secretion is at $\mathbf{p H ~} 5.0$ or less (Miura, 1928; Hardy, 1941; Cruickshank \& Sharman, 1934a, $b$ ). It has been assumed that bacterial implantation takes place within a few hours and for 2 or 3 weeks postnatally 'a simple homogeneous flora of Gram-positive bacilli, known as Döderlein's vaginal bacillus, is established in the vagina in association with a slightly acid non-purulent secretion' (Cruickshank \& Sharman, 1934b). Shortly after this the flora changes and until puberty normally comprises micrococci, streptococci, diphtheroids, but seldom 'Döderlein's bacillus' (Döderlein, 1892). At puberty and before menstruation, the flora again changes to one predominantly of lactobacilli, and remains so in normal individuals throughout the reproductive period. At menopause there is a final change to the mixed flora found before puberty (Pettit \& Hitchcock, 1933; Soeken, 1926; Dychno \& Dertschinsky, 1930). These changes are thought to be correlated with the appearance of glycogen in the mucosal epithelium induced by oestrin formation (Miura, 1928; Cruickshank \& Cruickshank, 1931; Cruickshank \& Sharman, 1934a,b). Döderlein's (1892) original thesis, also maintained by others, was that the production of lactic acid by the Gram-positive bacilli served as one of the protective measures against infection.

Organisms assumed to be 'Döderlein's bacillus' have been variously designated as Bacillus vaginae, B. vaginalis longus, B. vaginalis, Acidobacterium doederlinii, Plocamobacterium vaginae, Lactobacillus doederlein, Bacillus lacticus and Lactobacillus 
acidophilus (Bergey's Manual, 1948). The Gram-positive rods isolated in previous work are so incompletely described that it is impossible to know what they really were, except that they may often have been lactobacilli, or even diphtheroids. In a number of investigations diagnoses for 'Döderlein's bacillus' have been made from studies of smears only.

During an investigation at the U.S. National Institutes of Health by one of us (M.R.), the purpose of which was to explore the relation between bacterial and trichomonad metabolism, modern methods of study (Rogosa et al. 1953; Sharpe, 1955) were used to isolate and characterize vaginal lactobacilli from normal nonpregnant women. It was almost immediately apparent that the isolated strains did not form a homogeneous group, and certainly not within a species, since homofermentative and heterofermentative organisms were obtained.

\section{METHODS}

The vaginal secretions were obtained by the swab technique designed to minimize external contamination (Miura, 1928; Soeken, 1926; Cruickshank \& Sharman, $1934 a, b)$. The samples were plated on the selective lactobacillus medium of Rogosa, Mitchell \& Wiseman $(1951 a, b)$ and incubated at $37^{\circ}$ anaerobically for 4 days in an atmosphere of $90 \%(\mathrm{v} / \mathrm{v}) \mathrm{N}_{2}$ and $10 \%(\mathrm{v} / \mathrm{v}) \mathrm{CO}_{2}$. Isolations from representative colonies were made and replated as required to ensure purity.

The methods used for the identification of the isolates combined cultural, biochemical and serological techniques to establish correlations of characteristics. These methods have previously proved to be highly successful in characterizing lactobacilli from a variety of sources (Rogosa et al. 1953; Sharpe, 1955) and have been developed from the basic studies of Orla-Jensen $(1919,1943)$.

\section{RESULTS}

Thirty-five strains of lactobacilli from twenty-one individuals, aged $21-40$ years, were isolated; 21 of these isolates were studied in detail to determine their species designation. The remaining 14 strains were lost, but not before tests for gas production had been completed. Heterofermentative lactobacilli for the total sampling were found in approximately the ratio of $1: 4$ as shown in Table 1.

Fourteen of the 21 isolates were typically Lactobacillus acidophilus, and were so designated by means of the criteria of Orla-Jensen $(1919,1943)$, Rogosa et al. (1953), Sharpe \& Mattick (1957), Harrison \& Hansen (1950), de Man (1956), Wheater (1955), and others. Serological techniques for the confirmatory identification of L. acidophilus are not available since successful group antisera for either the agglutination or precipitin techniques have not yet been produced. The two strains of the second homofermentative species, Lactobacillus casei var. rhamnosus (Rogosa et al. 1953; Sharpe $\&$ Wheater, 1957) were typical in all respects, including possession of the group $\mathbf{C}$ antigen.

The remaining isolates were heterofermentative. Two of the strains of Lactobacillus fermenti had typical characteristics, including the group $\mathbf{F}$ antigen. However, two of the strains, although typical in other respects, did not react serologically and thus resembled many of the strains of intestinal origin.

In a previous examination by one of us (M. E. S.) of the faeces of twelve breast-fed infants 6-11 days old, in addition to the so-called Lactobacillus bifidus (Sundman, Björksten \& Gyllenberg, 1959), authentic lactobacilli were also isolated from three 


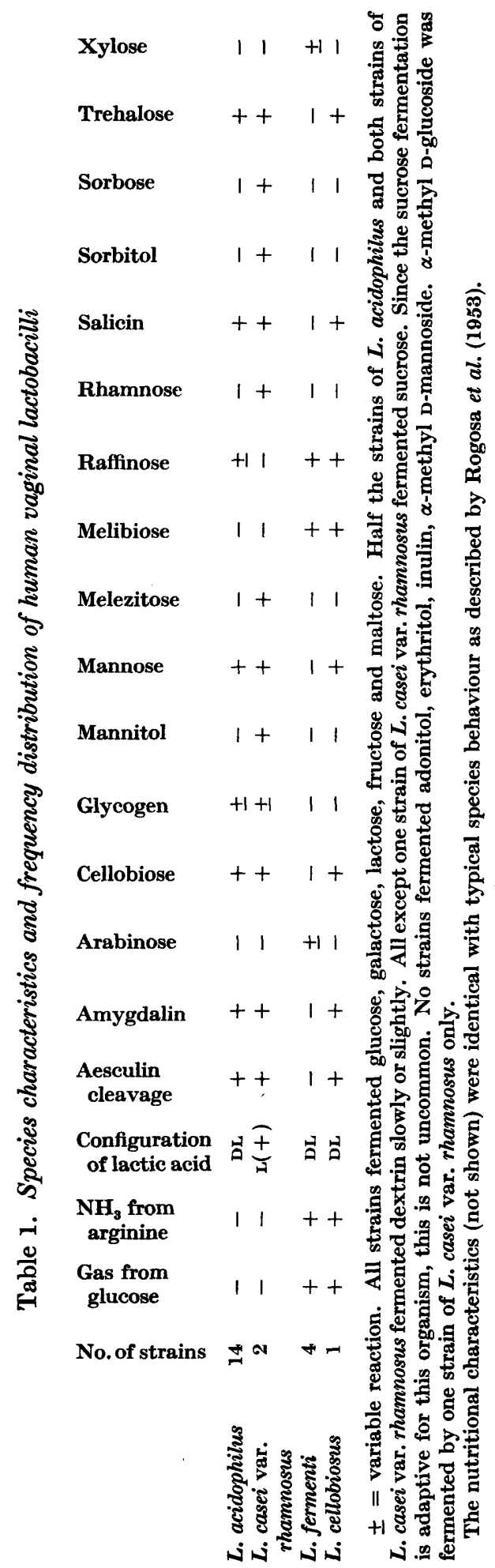


of the infants; these strains were all $L$. fermenti, giving the typical biochemical and serological reactions of this species. Witkowski (1985) showed that the mouth of the infant shortly after birth contains organisms in proportions corresponding closely to the flora of the mother's vagina. 'The intestine at birth is either sterile or contains a few bacteria; infection rapidly occurs, partly from above and partly from below' (Topley and Wilson's Principles, 1955). The strains of $L$. fermenti described here may also have had a similar origin. The heterofermentative strain of $L$. cellobiosus, a species previously isolated from the mouth, had the modal characteristics described by Rogosa et al. (1953).

Occasionally certain Leuconostoc species may be isolated from the medium designed for the selection of lactobacilli (Perry \& Sharpe, 1960). It is of incidental interest that $L$. mesenteroides was isolated in the present work and found to be identical with the organism as described by Garvie (1960). This appears to be the first reported isolation of this heterofermentative lactic acid coccus from the human vagina. It is also of interest since in morphology this organism often resembles the short coccobacillary forms of lactobacilli, particularly in acidic environments. Thus examinations of smears for 'Döderlein's bacillus' might be misleading in underestimating the real coccal population.

\section{DISCUSSION}

Except that Döderlein (1892) had most probably isolated a lactobacillus, the species identities of the vaginal lactobacilli have not previously been satisfactorily established. In many instances any rod-like bacterium was identified as 'Döderlein's bacillus' on the basis of morphology alone. Although Miura (1928) had identified the lactic acid produced by his isolate as the DL enantiomorph, it is impossible to identify the organism from the fragmentary data. Many species of lactobacilli produce DL-lactic acid. Thomas (1928), who used inadequate and somewhat questionable tests, concluded that 'Döderlein's bacillus' was Lactobacillus acidophilus, but recognized that this terminology was loose and generic, as was the case for the wide spectrum of oral lactobacillus species also previously designated as $L$. acidophilus (Rogosa et al. 1953; Tilden \& Svec, 1950).

Although Miura (1928) found that his isolate did not ferment glycogen, Wheater (1955) observed that $43 \%$ of her strains of Lactobacillus acidophilus did so. We have recently re-studied representative strains of Wheater's collection and have confirmed her results. On originally testing our isolates, none of our strains fermented glycogen. However, it was noted that the initial $\mathrm{pH}$ value of the medium was relatively high for lactobacilli ( $\mathrm{pH} 7 \cdot 0$ ). When the tests were repeated with 9 representative strains at more favourable $\mathrm{pH}$ values $(5 \cdot 0,5 \cdot 8,6 \cdot 5)$ five of them fermented glycogen, but usually weakly. This behaviour was not associated with consistent species activity but rather with individual strains and in repeated experiments seemed to be an adaptive and variable phenomenon, independent of anaerobiosis or aerobiosis. Thus it seems highly probable that these lactic acid bacteria obtain available carbohydrate from the enzymic conversion of glycogen if not other carbohydrates, by the tissues or by micro-organisms other than lactobacilli. Also a considerable heterofermentation in the vagina is strongly suggested by the present results.

The authors wish to thank Miss Diane Bramfitt for technical assistance. 


\section{REFERENCES}

Bergey's Manual of Determinative Bacteriology (1948). 6th ed. Ed. R. S. Breed., E. G. D. Murray \& A. P. Hitchens. Baltimore: Williams and Wilkins.

Cruickshank, J. \& Cruickshank, R. (1981). The bacterial flora of the vagina. In a System of Bacteriology in Relation to Medicine. Spec. Rep. Ser. med. Res. Counc., Lond. 8, 363.

Cruickshank, R. \& Sharman, A. (1934a). The biology of the vagina in the human subject. J. Obstet. Gymaec. Brit. Emp. 41, 190.

Cruickshank, R. \& Sharman, A. (1934b). The biology of the vagina in the human subject. II. The bacterial flora and secretion of the vagina at various age-periods and their relation to glycogen in the vaginal epithelium. J. Obstet. Gynaec. Brit. Emp. 41, 208.

Döbertarin, A. (1892). Das Scheidensekret und seine Bedeutung für Puerperalfieber. Zbl. Bakt. 11, 699.

Dychno, M. A. \& Dertschinsky, G. D. (1930). Untersuchungen der Vaginalmikroflora in verschiedenen Perioden des Kindesalters und in der Periode der Geschlechtsreife. Arch. Gymaek. 142, 551.

GarviE, E. I. (1960). The genus Leuconostoc and its nomenclature. J. Dairy Res. 27 (in the Press).

HARDY, G. C. (1941). Vaginal flora in children. Amer. J. Dis. Child. 62, 939.

Harrison, A. P. \& Hansen, P. A. (1950). Lactobacilli from turkeys. J. Bact. 60, 543.

MAN, J. C. DE (1956). De eigenschappen van einige stammen van Bacterien behorende tot het geslacht Thermobacterium Orla-Jensen. Ned. melk-Zuiveltijdschr. 10, 190.

MuUnA, H. (1928). Beiträge zum Studium über die Vaginalsekrete. Mitt. med. Akad. Kioto, 2, Heft 1, 1.

Orla-Jensen, S. (1919). The Lactic Acid Bacteria. Copenhagen: Andr. Fred. Host and Son.

Orla-Jengen, S. (1948). The Lactic Acid Bacteria. Copenhagen: Ejnar Munksgaard.

Perry, K. D. \& Sharpe, M. E. (1960). Lactobacilli in raw milk and in cheddar cheese. J. Dairy Res. 27 (in the Press).

Petrit, H. \& Hrtchcock, C. H. (1938). Normal flora of the prepuberal vagina. J. infect. Dis. 53, 872.

Rogosa, M., Mrtchell, J. A. \& Wrseman, R. F. (1951a). A selective medium for the isolation and enumeration of oral and faecal lactobacilli. J. Bact. 62, 132.

Rogosa, M., Mrtchell, J. A. \& Wiseman, R. F. (1951b). A selective medium for the isolation and enumeration of oral lactobacilli. J. dent. Res. 30, 682.

Rogosa, M., Wrseman, R. F., Mrtchell, J. A., Drsraely, M. N. \& Beaman, A. J. (1953). Species differentiation of oral lactobacilli. J. Bact. 65, 681 .

Sharpe, M. E. (1955). Serological classification of lactobacilli. J. gen. Microbiol. 12, 107.

Sharpe, M. E. \& MatTick, A. T. R. (1957). The identification of Lactobacillus acidophilus. Milchroissenschaft, 12, 348.

Sharpe, M. E. \& WheATER, D. M. (1957). Lactobacillus helveticus. J. gen. Microbiol. 16, 676.

Sokkxn, G. (1926). Die Vaginalflora im Kindes- und Pubertätsalter. Z. Kinderheilk. 40, 727.

Sundman, V., Björksten, K. \& Gyluenberg, H. G. (1959). Morphology of the bifid bacteria (organisms previously incorrectly designated Lactobacillus bifidus) and some related genera. J. gen. Microbiol. 21, 371.

Thomas, S. (1828). Döderlein's bacillus: Lactobacillus acidophilus. J. infect. Dis. 43, 218.

Tulden, E. B. \& Svec, M. (1950). Types of lactobacilli isolated from saliva. J. dent. Res. 29, 659.

Topley and Wilson's Principles of Bacteriology and Immunity (1955). 4th ed. Ed. G. S. Wilson \& A. A. Miles. London: Arnold.

Wheater, D. M. (1955). The characteristics of Lactobacillus acidophilus and Lactobacillus bulgaricus. J. gen. Microbiol. 12, 123.

Witkowskr, R. (1935). Aerobe Mundhöhlflora bei Mutter und Kind. Z Zbl. Bakt. 133, 334. 